Iwona Polucha, $\mathrm{PhD}$

University of Warmia and Mazury in Olsztyn, Poland Faculty of environmental management and agriculture

Department of landscape architecture

E-mail: iwona.polucha@uwm.edu.pl

ORCID ID 0000-0002-8283-1785

\title{
THE HISTORICAL DETERMINANTS CREATING A SACRED SPACE IN THE LANDSCAPE OF THE WARMIA AND MAZURY REGION
}

\begin{abstract}
A sacred space is a complement of sacred objects and its development enhances the understanding of a religious message. This paper shows aspects of the spatial arrangement around churches commonly found in spaces evoking the historically-conditioned symbolism of green components. The creation of a sacred space as a place for meditation and religious experience is shown through the prism of religious meaning and values of selected objects of the Marian sect in the Warmia and Mazury region.
\end{abstract}

Key words: worship, religious building, symbolism, green area.

\section{HISTORYCZNE UWARUNKOWANIA KREACJI PRZESTRZENI SAKRALNEJ W KRAJOBRAZIE WARMII I MAZUR}

Streszczenie: Przestrzeń sakralna jest dopetnieniem obiektów kultu, a jej zagospodarowanie ułatwia odczytywanie $i$ rozumienie przestania religijnego. $W$ artykule poruszono aspekty aranżacji otoczenia kościołów powszechnie wystęujących $w$ krajobrazie warmińsko-mazurskim, przy których warto kontynuować uwarunkowana historycznie symbolikę komponentów zieleni. Zasadność kreowania przestrzeni sakralnej jako miejsc medytacji $i$ przeżyć religijnych ukazano przez pryzmat znaczenia religijnego i wartości wybranych obiektów kultu maryjnego na Warmii i Mazurach.

Stowa kluczowe: kult, obiekt sakralny, symbolika, teren zieleni.

\section{Introduction}

Christianity has incorporated both local traditions of worship and biblical symbolism as well as the majority of archetypical notions from Judaism, for instance, the concept of the Holy Land, which is associated with the meaning of sacral space or the sacrum, expressed by phenomena and the powers of nature. A green grove or a garden prompts spiritual values, praying and contemplation. The myth of the biblical paradise arising from Christian worship was one of the most important factors that shaped the attitude of man towards nature. Numerous images of the garden are in the background of scenes and depictions from the lives of Mary, Jesus and the saints, to whom trees and flowers were assigned as attributes and ornaments. The tree itself receives a novel, universal dimension of a cross as the Tree of Salvation [17, p. 102109]. The biblical spring was also depicted symbolically with a well or a fountain situated at the confluence of alleys located in a garden (being its equivalent) on a square plane surrounded by walls. Four sides symbolized the rivers of Eden as well as the evangelists and cardinal virtues, namely: wisdom, abstinence, fairness, and bravery [10, p. 112-229; 14, p. 109-119]. 
The objective of this paper is to assess the need for including historical determinants and the symbolic dimension of the elements of sacral space in designing green spaces near religious sites.

\section{Symbolism of sacral space}

A human being, as a creature who expresses his internal experiences, needs symbols to come closer to everything that is spiritual; experiencing their rich content may often affect a person more than words. Symbols combine different things in one total experience, whereas language may only partially and gradually explain what symbols depict. Since the first centuries, Christians have used symbols in addition to the alphabet (and probably even more so) as not all of them could read. Therefore, while delivering their sermons, the Fathers of the Church drew upon examples from the world of symbols [5, p. 7-192].

Thanks to symbolic, aesthetic and nurturing features and determined boundaries, the sacral garden is a special and selected space. As a closed system, it has gates linking the things that are godlike - the sacrum with the external world - profanum. It is sometimes a model of the cosmos and a projection of creation. In a modern definition, the garden is the highest achievement of civilisation, where the effect of human thought and planned order combine with nature. One may say that the sacral garden is a work of the utmost perfection understood as the harmonic co-existence of nature and culture. The cross, being the symbol of Passion, is one of the most meaningful Christian symbols and, thus, the reflections of sacral assumptions often refer to this symbolism. The shape of the fish is important in this context, as it alludes to the multiplication of food by Jesus. Alfa and omega are equally important in Christianity - these are the symbols of the beginning and the end [15, p. 58-63].

The world of plant composition has brought invaluable benefits to religion and all of human culture. Both primordial polytheistic beliefs and religions that were subsequently created, including Islam and Judaism, present timeless rewards in the same manner - these are great gardens that are rich in everything that is valued on Earth: lands of beauty, happiness and fulfilled dreams and desires "Indeed, the righteous will be in gardens and pleasure..." [11, p. 29]. One should remember that vegetation is accompanied by inanimate elements which many have a symbolic dimension such as water, wood, rocks or clusters of stones. In a space with sacral meaning, there is always an expanded symbolic frame, richness of meaning and a fascination that is elicited by the power and capacity of nature for cyclic renewal [13, p. 109$119]$.

\section{Religious symbolism through the prism of history}

A sacral space is a reflection of a godlike paradise. In religions based on the Bible, Eden was the first garden: a land of eternal happiness from which the proto-parents Adam and Eve were expelled. Garden art - understood as an amazing mosaic of smells, sounds and light that originated from the human desire to comprehend the secrets of creation - lays at the basis of images of the paradise garden. This resulted from constant attempts to create a garden to equal the work of the Creator. The biblical perception of paradise that was used in garden designs, was a model of the Cosmos regarded as a metaphor of a perfect spiritual life. The image of the universe as a "paradise on the Earth" was divided by four rivers: (Gihon, Pishon, Tigris and Euphrates) that diverged into different directions of the world. A nurturing spring was the centre of a recreated paradise. The whole image was a specific magical area filled with figures and symbols; it indicated a spiritual pathway towards godlike secrets [13, p. 109-119; 3, p. 17-18]. The sacral space can be thus regarded as a "symbol of cosmic arrangement, seclusion, contemplation, and innocence" [2, p. 245]. 
The paradise garden became a manifestation of the human need to oppose primordial nature, which was understood as chaos. In the Middle Ages, greenery was mainly arranged as monastery gardens. As mandated by their monastic rules, Benedictine monasteries had to have a garden. Many of the activities of these monks exerted a significant impact on the shape of gardens and the cultivation of ornamental and agricultural plants in Europe. Many monasteries also included the cultivation of land and gardens. Based on their usage, monastery gardens were divided into ornamental and agricultural elements. The first group included agricultural, medical, hospital, and cemetery gardens, while the second comprised a patio (a constantly repeated component of monastic premises) and an abbot's garden [8, p. 87-88; 18, p. 73-80].

The patio was fitted into a square of monastic cloisters and was geometrically divided into planes based on the rule of "ad quadratum" [16, p. 1-351]. Even in antiquity, the square was considered a perfect figure. In the Middle Ages, it remained a privileged figure and was often used as the basic module for constructions. The quadrature was quickly adopted as the basis for planning and designing gardens due to its practical values, not only for monasteries, but also in renaissance and baroque gardens $[9$, p. 61-64; 11, p. 112-229].

Since ancient times, gardens have been an inherent element of holy sites. Initially, places dedicated to God were surrounded by the beauty of wild nature. Over time, temples were accompanied by carefully-designed garden compositions on a different scale. Past styles may also be found in modern times. Designed greeneries accompany temples and monastic premises as well as sanctuaries, calvaries, wayside shrines and wayside crosses. In Poland, the scale of garden premises is diversified and adjusted to the size of a sacral object. In all types of sacral gardens, garden elements are used in a double role: both aesthetic and meaningful based on Christian symbolism. Despite regional diversity, sacral gardens have a durable and identifiable spatial structure. The structural stability that results from ancient traditions forms the features and identity of native landscapes [8, p. 87-88].

\section{Religious symbolism of the tree}

The tree is a special symbol in Christian culture; it is portrayed as an element that links heaven and the Earth through its trunks and roots seated deep in the ground. The trunk signifies the existence on earth between life underground and life in heaven. The tree is also a reflection of revival and life by its development throughout the year. Ever-green coniferous trees are a symbol of life and immortality, whereas trees that lose leaves for the winter and come back to life in spring are a symbol of revival [4, p. 47].

Nature and natural phenomena were worshipped even in prehistoric times. In Babylonian and Assyrian cultures, the holy mountain and the holy tree are also found. The worship of the power of nature also lies at the source of Islam, which, for instance, portrays the effects of God in plants. The tree plays an important role in each perception of paradise. Leaves cast a lifegiving shadow and pure water and rivers of milk and honey flow from beneath the roots. Both in the Old and in the New Testament, trees have numerous meanings and wide metaphoric connotations. In the ancient Jewish culture, there was the worship of rocks, hills and trees, particularly oaks and terebinths, under which sacrifices were laid. Greeks and Romans associated individual tree species with symbolism: olive trees with affluence, cypress with mourning, bay and oak with wisdom and bravery. Before they started to erect temples, their places of worship were located in holy groves [9, p. 61-64].

The worship of trees as the axis of the cosmos and symbolizing eternity is also found in northern tribes. In the German mythology, there is the "tree of the universe" with a much expanded function. Gods were seated on boughs, while beneath the roots was a freezing and dark land resembling hell. Slavs had their own holy groves with oaks, limes, maples, ashes, and elms. 
Celts worshipped trees in yew groves and oak groves and they - as the first ones - created sanctuaries. Apple trees are commonly found in the literature and iconography. Until now, a special emotional attitude toward trees has persisted. Churches and cemeteries surrounded by old lime trees have become a typical element in the Polish countryside. Wayside shrines and votive figures are situated on or under trees. Trees with a holy painting are often carefully preserved relics in lanes, parks or along small roads [17, p. 102-109].

\section{Religious symbolism of plants}

Christian symbolism of plants refers to both individual species and their colours (tab. 1). Apart from green, red is also a privileged colour that is often evoked in the symbolism of gardens. The colours of roses, blood, juice or wine are the colours of life and death, ecstasy and oblivion. A red rose among thorns, with a colour that resembles blood, is both the attribute of martyrs and a symbol of Passion. A white rose without thorns symbolizes the virtues of Mary, her Immaculate Conception and virginity. Moor compared the birth of Christ by the virgin to roses blooming on a thorny bush, whereas Dante perceived Mary as a mystic rose [5, p. 7-192; 21, p. 143-144].

Among flowers, representing the seasons (particularly spring), the rose is the most valued due to its beauty and fragrance. Greeks trace its name back to "flow, effuse" as streams of fragrance effuse from it, yet at the same time its living substance evaporates and thus it fades so quickly. The ancients were impressed both by the splendour of the rose and its short life. Pilny the Elder wrote: "Nature gave birth to flowers and odours for a short time; this should caution people - the things that bloom beautifully (such as roses, lilies, and violets) fade quickly". The Bible enumerates the rose among aromatic plants to which eternal wisdom is compared. According to the Wisdom of Sirah, the children of God shall bloom as the rose. Thorns of the rose also have a symbolic meaning as they picture sins and their consequences, pain and sufferings. Thorns foul the temple of suffering of the Saviour "... among the thorns of putridity, there is virginity enlightened and free of thorns". The Immaculate Virgin Mary is the true "rose among thorns" [12, p. 64-71; 19, p. 57-58].

The symbolism of the lily representing the Virgin Mary is widespread; it is an inherent attribute of the Annunciation, symbolizing the virginity of Mary - three lilies are a sign of triple virginity: before, at and after the birth of Christ [5, p. 7-192].. In Palestine, the lily can be found among thorn bushes, where it grows lusciously. The Immaculately Conceived Mary is identified with a lily that blooms among the thistles and thorns of sinful human beings. Christ himself calls in the Evangels to admire flowers "Look at lilies as they grow (...), even Salomon in all his splendour was not dressed equally to one of them" [Matthew, 6, 28, The New Testament -1 , p. 592-1433]. As decoration in churches, flowers have been a silent tribute to God since ancient times. Roses and lilies were offerings that could be placed around the altar during processions [5, p. 7-192].

Vegetation that was used to decorate wayside shrines and crosses was planted according to local traditions. Therefore, different plant species can be found near churches, holy figures or in cemeteries. Yew trees, thujas, and ivies are commonly planted as they are not only decorations but also a manifestation of the belief in eternal life. Plants associated with the worship of Mary are often used, such as white lily (Lilium candidum L.), iris (Iris sp.), and rose (Rosa sp.). Wayside shrines and crosses are often located next to trees that are strongly associated with Christian traditions, thereby signifying the connection between heaven and earth. High greenery with a sacral meaning is represented by trees that are deeply seated in folk traditions and that were often perceived through the prism of beliefs. In many regions of Poland, their glorification is a remainder of the Slavic worship of trees. This mainly concerns trees that surrounded temples 
with their boughs, enshadowed graves, chapels, wayside shrines, figures, paintings depicting the saints, wayside crosses and holly springs [20, p. 143-144].

Particularly trees involved in apparitions of Mary were worshipped. This was usually the lime (Tilia sp.) often regarded as a protective tree. The other commonly used tree species included maple (Acer sp.) and sycamore (Acer pseudoplatanus L.), protecting against misfortune, ash (Fraxinus sp.) and briars (Crataegus sp.) providing peace and justice, affluence and health, and oak (Quercus sp.) which was the symbol of power, durability and strength [8, p. 87-88].

Table 1

Selected symbolic plants used in sacred spaces

\begin{tabular}{|c|c|c|}
\hline Plant & $\begin{array}{l}\text { oo of page } \\
\text { in lexicon* }\end{array}$ & Sacral meaning \\
\hline Ivy & $(50)$ & $\begin{array}{l}\text { Symbol of eternal life and fidelity; it strongly binds to its } \\
\text { substrate }\end{array}$ \\
\hline Pansy & $(54)$ & Herb that is called "the flower of the Holy Trinity" \\
\hline Cedar & $(58)$ & $\begin{array}{l}\text { Ever-green plant, a symbol of paradise and eternal life as well } \\
\text { as strength and beauty in the Old Testament }\end{array}$ \\
\hline Cypress & $(69)$ & $\begin{array}{l}\text { Symbol of the paradise and eternal life; according to Sirach, it } \\
\text { is a symbol of wisdom and of selected people (including } \\
\text { Mary); in Poland, a symbol of mourning and death }\end{array}$ \\
\hline Lemon & $(69)$ & $\begin{array}{l}\text { Symbolizes life and harvest; it is used for weddings, } \\
\text { christenings and funerals }\end{array}$ \\
\hline Oak & (76) & $\begin{array}{l}\text { The holy tree for Germanic people; it symbolizes strength and } \\
\text { eternal life (hard wood; it resists decomposition) }\end{array}$ \\
\hline Olive tree & $(84)$ & $\begin{array}{l}\text { Symbolizes eternal life and immaculate and healing grace of } \\
\text { the Mother of God }\end{array}$ \\
\hline Pumpkin & $(85)$ & Symbolizes the transitory nature of human life \\
\hline Violet & $(103)$ & $\begin{array}{l}\text { Identified with the humility of Mary; the colour indicates the } \\
\text { Passion and godlike Kingdom of Christ }\end{array}$ \\
\hline $\begin{array}{l}\text { Alpine } \\
\text { violet }\end{array}$ & $(104)$ & $\begin{array}{l}\text { Plant of the Virgin Mary; red colour in the middle of the } \\
\text { flower refers to the heart of Mary that bleeds of pain }\end{array}$ \\
\hline Dianthus & $(113)$ & $\begin{array}{l}\text { Came in the 13th century together with the Knights of the } \\
\text { Cross; sanguine flower is a symbol of passion, whereas leaves } \\
\text { and flowers with the shape of a nail indicate the future death } \\
\text { of Christ on the cross }\end{array}$ \\
\hline Iris & $(124)$ & $\begin{array}{l}\text { Plant of the Virgin Mary, (from Greek, it means "a rainbow"); } \\
\text { it symbolizes reconciliation of humans with God, the alliance } \\
\text { renewed before the sacrificial death of Christ }\end{array}$ \\
\hline Maple & $(145)$ & Tree that protects against misfortune \\
\hline Clover & $(157)$ & Reference to the Holy Trinity \\
\hline $\begin{array}{l}\text { Lily of the } \\
\text { valley }\end{array}$ & $(158)$ & $\begin{array}{l}\text { Smell and colour of the flower are identified with tenderness } \\
\text { and virgin purity of Mary }\end{array}$ \\
\hline $\begin{array}{l}\text { Wood } \\
\text { avens }\end{array}$ & $(170-171)$ & $\begin{array}{l}\text { Blooming in yellow; it is used as a herb; it indicates that } \\
\text { Christ is the Saviour of the world }\end{array}$ \\
\hline Lily & $(177-178)$ & It was a symbol of light and life in the Mediterranean region; \\
\hline
\end{tabular}




\begin{tabular}{|c|c|c|}
\hline Plant & $\begin{array}{l}\text { № of page } \\
\text { in lexicon* }\end{array}$ & Sacral meaning \\
\hline & & $\begin{array}{l}\text { it commonly means trust in God's grace, clerical authorities; } \\
\text { red flowers indicate the Passion, whereas white flowers } \\
\text { signify virgin-like purity and innocence, the attributes of Mary }\end{array}$ \\
\hline Lime & $(180)$ & Regarded as a protective tree \\
\hline Mallow & $(186)$ & Symbol of the healing power of Mary \\
\hline Marguerite & $(189)$ & $\begin{array}{l}\text { Signifies a pearl, the symbol of cried tears; it indicates the } \\
\text { sufferings of Christ and the martyrs }\end{array}$ \\
\hline Almond & $(203)$ & Spring-blooming symbol of God's vigilance \\
\hline Calendula & $(213)$ & $\begin{array}{l}\text { (from German) a favourite of the Sun; a sign of the healing } \\
\text { power of Mary }\end{array}$ \\
\hline Narcissus & $(215-216)$ & $\begin{array}{l}\text { Symbol of a mystic bride (together with lily and lily of the } \\
\text { valley); it also signifies the Resurrection }\end{array}$ \\
\hline Columbine & $(237)$ & $\begin{array}{l}\text { Herb that symbolizes fertility; } 7 \text { flowers are interpreted as } 7 \\
\text { gifts of the Holy Spirit; leaves refer to birds-doves, also } \\
\text { associated with the Holy Spirit }\end{array}$ \\
\hline Nut & $(237-238)$ & $\begin{array}{l}\text { Symbolizes Christ; bitter green cover signifies sufferings of } \\
\text { Jesus on the earth; wooden shell indicates the wood of the } \\
\text { Cross, whereas sweet fruit means the God's nature that gives } \\
\text { life; also a symbol of harvest and fertility }\end{array}$ \\
\hline Delphinium & $(239-240)$ & $\begin{array}{l}\text { Symbol of the nobility and chivalry; it soothes eye pain and } \\
\text { thus the reference to salvation from spiritual blindness thanks } \\
\text { to Christ and Mary }\end{array}$ \\
\hline $\begin{array}{l}\text { Thistles and } \\
\text { briars }\end{array}$ & $(240)$ & Onerous weed; initially a symbol of sins and difficulties \\
\hline Primerose & $(251)$ & $\begin{array}{l}\text { Old herb; it grew at the spot were St. Peter dropped the key to } \\
\text { heaven; also a symbol of the Mother of God who, via her } \\
\text { Godlike Son, opens heaven for people }\end{array}$ \\
\hline Stone pine & $(253)$ & Symbolizes life and fertility \\
\hline Snowdrop & $(262)$ & $\begin{array}{l}\text { Symbol of hope; the attribute of the Mother of God, a source } \\
\text { of Christian hope }\end{array}$ \\
\hline Rose & $(277-278)$ & $\begin{array}{l}\text { Red flowers: a symbol of sanguineous martyrdom of the } \\
\text { saints; white flowers: Mary's flowers }\end{array}$ \\
\hline Chamomile & $(279-280)$ & Herb that signifies the healing power of Mary \\
\hline Rockfoil & $(293)$ & $\begin{array}{l}\text { In the Middle Ages it was believed that this plant, growing in } \\
\text { rocky slits, could crack stones; it was referred to in the } \\
\text { Resurrection of Christ from the tomb. }\end{array}$ \\
\hline Sunflower & $(294)$ & Symbol of soul that heads towards God \\
\hline Daisy & $(299)$ & $\begin{array}{l}\text { According to legend, it grew from tears cried by Mary during } \\
\text { the flight to Egypt }\end{array}$ \\
\hline Sage & $(309)$ & Herb that is identified with the healing power of Mary \\
\hline Tulip & $(347)$ & $\begin{array}{l}\text { Symbolizes vanity, paltriness and insignificance of all } \\
\text { evanescent things; a symbol of death }\end{array}$ \\
\hline Willow & $(355)$ & $\begin{array}{l}\text { Branches used in religious rituals; a vital plant that, when } \\
\text { clipped, produces new stems - a symbol of the Evangel whose }\end{array}$ \\
\hline
\end{tabular}




\begin{tabular}{|l|c|l|}
\hline \multicolumn{1}{|c|}{ Plant } & $\begin{array}{c}\text { № of page } \\
\text { in lexicon* }\end{array}$ & \multicolumn{1}{c|}{ Sacral meaning } \\
\hline & & $\begin{array}{l}\text { message is always current, regardless of the area on the globe } \\
\text { where it is delivered }\end{array}$ \\
\hline Vine & $(357-358)$ & Symbol of the Church and Christ \\
\hline Anemone & $(372)$ & $\begin{array}{l}\text { Flower that quickly fades; it symbolizes death (pheasant's } \\
\text { eye); a symbol of the martyrs' blood and sufferings of Christ }\end{array}$ \\
\hline
\end{tabular}

* Source: [22] Siebiert J. 2007. Leksykon sztuki chrześcijańskiej. Tematy, postacie, symbole. Wyd. Jedność, Kielce.

\section{Religious symbolism of digits, numbers and colours}

Digits, numbers and colours carry a clear message in Christian symbolism with a special meaning attributed to the following digits and numbers: $3,4,5,6,7$, and 12 . The ancient mythologies depicted god-like triads (the Egyptian triad: Osiris - Isis - Horus; the Babylonian triad: Sin - Shamash - Ishtar) and the digit "three" has since always symbolized universalism, perfection and completeness. In the Bible, "three" represents the Trinity of God (three God-like Persons) and refers to god-like virtues: faith, hope and love as well as to the Resurrection after three days and nights. This digit has also a pejorative meaning, as Satan teases Jesus three times in the desert, Peter abjures Christ three times, and Cimmerian darkness lasted three days [1, p. 592-1433]. In general, the digit "three" may be regarded as a symbol of everything that is godlike (sacrum).

The digit "four" signifies the nature of cosmic unity: the cardinal directions, main winds and seasons of the year are all four each. In Eden, a stream separates into four paradise rivers and, in the Apocalypse, God's throne is watched over by four animals that symbolize the whole world created by God. This digit carries a clear message in the persons of Evangelists, the riders of the Apocalypse and the division of cardinal virtues (justice, bravery, wisdom, and moderation). The name of the first man is composed of four letters, of which each is the beginning of the Greek names of cardinal directions: Anatole, Dysis, Arktos, and Mesembria [7, p. 25-270]. It may be thus assumed that "four" symbolizes the things that are telluric (profanum).

The sum of "three" and "four" is "seven", which in Christianity is a symbol of completeness (a combination of god-like elements, namely, the human soul, with a telluric human body; it is also a combination of virtues). On the seventh day, God rested after creating the world; Noah waited seven days for a dove to return; the Paternoster includes seven attempts; there were seven years and fat cows and the same number of skinny ones; and lastly, there are seven holy sacraments and an equal number of cardinal sins. The digit "seven" symbolizes the unity of two worlds; it is their combination which signifies completion [1, p. 592-1433].

Creatures that were hostile towards God had their numerical name which was symbolized by "six" and multiples thereof. It is suspected that this digit was used to describe Nero, the enemy of Christians. The number "twelve" (permeation of the digits "three" and "four") is mainly associated with the Apostles who are the pillars of Christian church. In the Old Testament, twelve generations of Jacob, who formed Israel, are mentioned; twelve scouts were sent to the promised land and twelve bulls supported the "sea" of bronze [7, p. 25-270]. The Book of Revelation also evokes the cosmic meaning of this number - "A woman carries on her head a crown of twelve stars" [Ap 12,1 - 1, p. 592-1433] as a reflection of animals from zodiac signs; the old men gathered around the throne, twelve on each side. In addition, the number one hundred and forty-four thousand is also symbolic and signifies the saved, namely, twelve thousand chosen persons from each generation [1, p. 592-1433]. 
The meaning of colours in Christian religion is important as they describe different attributes of saints and God, which is reflected in using chasubles during ecclesial ceremonies. White symbolizes the purity and innocence of Mary and the salvation of the world by Christ; blue signifies perfection and eternity; red - martyrdom of Christ (the coat put on his shoulders after whipping was purple) yet also anger and violent emotions; violet - humility as well as dignity and authority; silver symbolizes purification, justice and pure conscience (St. Anne, Mary's mother, is called "the mother of silver" and is the patron of silver mines), whereas gold signifies internal richness and all things that are telluric and transient [7, p. 25-270].

\section{Small sacral architecture}

Crosses, figures of saints and shrines are objects with a special meaning in the landscape. Of them, the most precious include old, traditional shrines with the imprint of passing time engraved in rings of wood or in stones and located somewhere under an aged tree or the majestic green meadows surrounded by colourful compositions of natural flowers. Their presence is a reflection of human spiritual needs as well as the faith of former generations. They are found in the natural environment all over Poland. The form of a shrine was inspired, for instance, by traditions of native architecture. Shrines were built from wood and bricks and were ornamented with a roof of tiles or steel sheet and sometimes covered with plaster or paint. Shrines and crosses are most often surrounded by a small rail fence which emphasizes the uniqueness of such a place. The interior of a small garden is filled with plants associated with Christian symbolism. Around a cross, the highest layer of plants is often composed of common lilac (Syringa vulgaris L.) and rugosa rose (Rosa rugosa THUNB.) bushes as well as sunflowers (Helianthus sp.) and mallow (Alcea sp.). The lower layer of plants includes coneflowers (Rudbeckia sp.), irises (Iris sp.), day lilies (Hemerocallis sp.), and nasturtium (Tropaeolum sp.) [8, p. 87-88; 16, p. 58-63].

\section{Symbols in the history of sanctuaries of the Virgin Mary in the Warmia Archdiocese}

The history of the Warmia Archdiocese sanctuaries indicates the great role of the power of nature and the symbolism of trees in the development of places where the Virgin Mary is worshipped. The awareness of the value of these objects allows for a deeper insight into the nature of designing new sites with complex Christian symbolism.

\section{Gietrzwałd - The Sanctuary of the Mother of God}

The history of the church in Gietrzwałd dates back to the early $14^{\text {th }}$ century (fig. 1). A temple was built at the turn of the $15^{\text {th }}$ and $16^{\text {th }}$ century and developed in the $19^{\text {th }}$ century. Its furnishings are neo-gothic and the style is eclectic. Since 1970, it has had the status of a smaller basilica. The history of the sanctuary entwines two elements: a graced painting and the $19^{\text {th }}$ century revelation of the Mother of God. From 27 June to 16 September 1877, the Mother of God appeared for two girls: thirteen-year-old Justyna Szafryńska and twelve-year-old Barbara Samulowska. She spoke to them in Polish and appeared over a maple tree (that today does not exist) near the church. The visionaries disseminated the worship of Mary and sanctified a spring that was blessed by the Mother of God. The revelations brought about an inflow of pilgrims and also caused the persecution of believers and priests from Gietrzwałd by invaders. At the spot where the Mother of God appeared, a shrine with the figure of the Blessed Virgin Mary and a fragment of wood from the maple was built. The rosary alley leading to the spring and the scenic way of the cross also have a symbolic dimension [22c, access 2015-01-23]. 


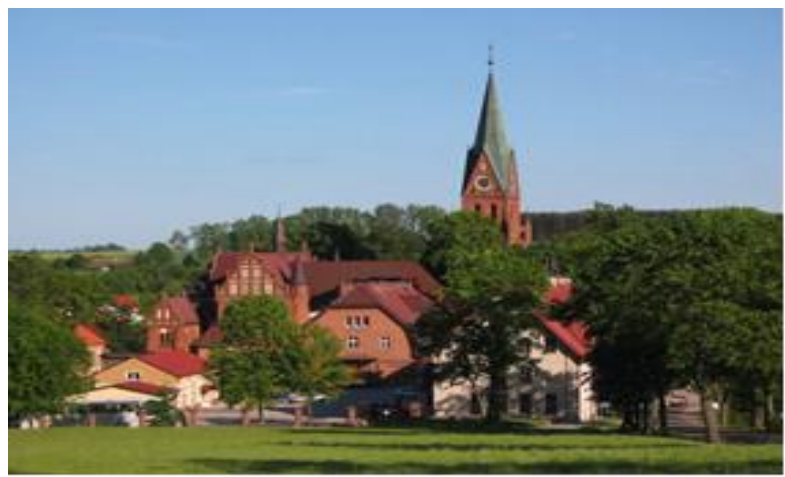

Ryc. 1. Sanktuarium Matki Bożej

Gietrzwatdzkiej. Źródło: A.

Elkhatib

Fig. 1. The Sanctuary of the

Mother of God. Source: A.

Elkhatib

\section{Ketrzyn - the Sanctuary of the Blessed Virgin Mary, the Mother of Mercy}

Priests who were educated in, or originated from, Vilnius and worked in the St. George parish contributed to popularizing the worship of Mary in the Kętrzyn region. The church, which dates back to 1359 and resembles a castle, has formed the panorama of the town for ages. It is a classic type of medieval fortified church. In 1525-1946, the church was used by Protestants and it was later returned to Catholics. The basement of the church served as a Teutonic prison - here, according to legend, a prisoner was held for whom Mary appeared and asked him to sculpt her figure. The Teutonic Knights perceived this event as supernatural and freed the prisoner, who hung the figure of Mary on a roadside lime tree on his way to Reszel. This spot later became famous for miracles and healings and was the origin of the sanctuary in Święta Lipka [22a, access 2015-03-03].

\section{Święta Lipka - the Sanctuary of Świętolipska, Mother of God}

The sanctuary in Święta Lipka is called the "Częstochowa of the North" (fig. 2) and its history dates back to the 14th century. At the spot where the released convict from Kętrzyn hung the figure of the Mother of God, a 8x12 m chapel was built with a lime extending through a hole in the roof. According to the documents from the $15^{\text {th }}$ century, the fame of the sanctuary reached beyond the borders of the diocese. The inflow of pilgrims continued despite the demolition of the church in 1524, its location in a Protestant region and a ban on pilgrimages and the worship of Mary. Since the Reformation, Święta Lipka has been a destination for pilgrims, as well as for Evangelists. Pope John Paul II designated the church as a small basilica in 1983 [22e, access 2015-02-09].

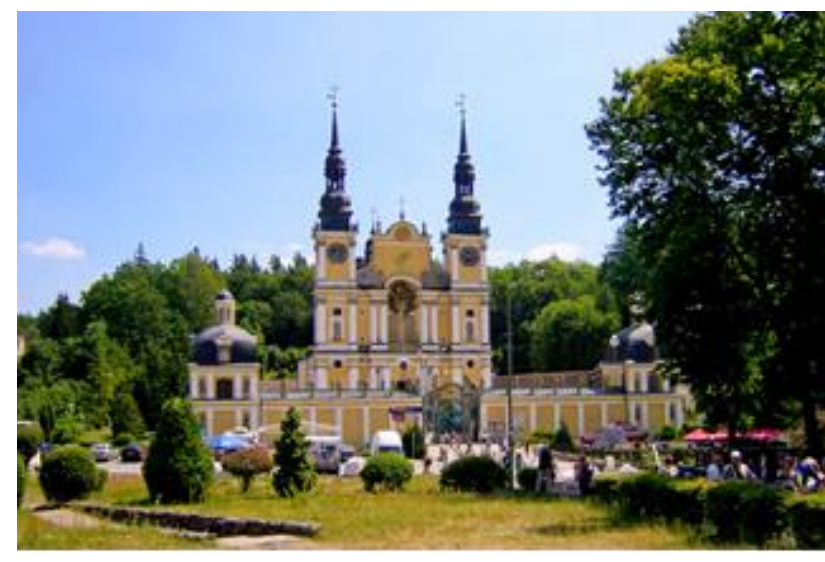

Ryc. 2. Sanktuarium Matki Bożej Świętolipskiej. Źródto: A. Elkhatib

Fig. 2. the Sanctuary of Świętolipska, Mother of God. Source: A. Elkhatib

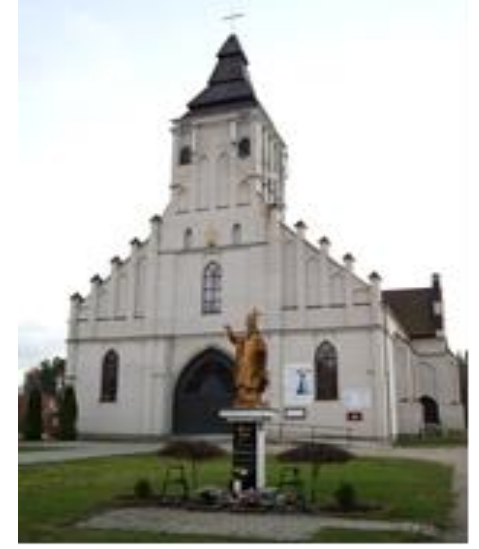

Ryc. 3. Sanktuarium Matki Boskiej Fatimskiej w Olsztynie. Źródto: [21b] Fig. 3. The Sanctuary of Fatima, Mother of God. In Olsztyn. Source: [21b] 


\section{Stoczek Klasztorny - the Sanctuary of the Mother of Peace}

The church from 1671 is a baroque building laid in stone in the shape of rotunda with a tower. The furnishings of the church originate from the $18^{\text {th }}$ century. The church was built on the site of a former shrine that commemorated the discovery of a figure of the Mother of God in a trunk of an old oak by two girls, although its creation in its modern shape was associated with the political situation after the Swedish occupation. The history of the sanctuary after the war is related to the imprisonment of Cardinal Stefan Wyszyński, the Primate of Poland. He was kept in the church from 12 October 1953 till 6 October 1954; during this period he spiritually gave himself over to the mother of God. The Pope John Paul II granted the church in Stoczek the status of a small basilica on 9 May 1987. Since 1957, the Marian Order has maintained the sanctuary [22d, access 2015-02-23].

Olsztyn - the Sanctuary of Fatima, Mother of God

A parish dedicated to Fatima, Mother of God in Olsztyn was established in 1995 (fig. 3). Located on the outskirts of the city, the church with a tapered shape plays an important role in the spiritual development of residents from nearby housing estates. The origin of the worship of Mary refers to Fatima, where her revelations over a holy oak were observed in 1917 and thus the symbolism of trees is of special importance in this space. This town situated in central Portugal, approximately $130 \mathrm{~km}$ from Lisbon and to the south-east of Leiria, and is nowadays a global destination for pilgrims. There, the Mother of God told three children - small shepherds (Lucy, Francis, and Hyacinth) to say the rosary and build a chapel dedicated to her. Initially, next to the oak over which the Mother of God appeared, a wooden gate was put at the site where believers prayed. Then, a temporary chapel was built on 28 April 1919. On 13 October 1930, the Bishop of Leiria approved the credibility of the revelation at Fatima and gave permission for official and local worship of the Rosary Mother of God. On 13 May 1953, Cardinal Manuel Cerejeira, the Patriarch of Lisbon, consecrated a new temple that was built in 1928-1953 on the scheme of a Latin cross with 14 chapels that, together with the sanctuary, symbolized the mysteries of the rosary. The temple was consecrated on 7 October 1953 and since 1954, it has carried the status of basilica [6, p. 20]. In the parish of Olsztyn, on the $13^{\text {th }}$ day of month, from May to October, there are church services held which are dedicated to the Mother of God from Fatima. They include: the Litany of the Blessed Virgin Mary, Holy Mass, the Rosary of Fatima with a procession to five rosary mysteries outside the chapel and an adoration vigil in front of the Holy Sacrament [22b, access 2015-07-09]. The Fatima church services proceed outside the church around the sacral space. In the surroundings of the sanctuary in Olsztyn, there is still a need for depicting the value of historical revelations by means of the symbolic meaning of greenery.

\section{Summary}

The notable examples of the worship places, including those situated in the Warmia region, confirm through their origins the strong connections between religious events and the natural environment. A review of the history of sanctuaries in the Warmia region demonstrates the special role of the tree in the sacral spaces. The privileged species include oak (Quercus sp.), lime (Tilia sp.), and maple (Acer sp.). The worship of revelations is worth continuing by introducing high greenery and flowering plants to areas near the churches. The selection of species should be based on native vegetation. The picture may be complemented by all elements that are deeply rooted in Christianity for religious reasons, historical determinants and local traditions (for instance, a cross, a gate or a spring). Combinations of these elements put into groups and colourful compositions as well as the type of material (water, wood, and rocks) also have a symbolic message.

A sacral space, as a special place where it is possible to spiritually reconcile with God, requires special attention and care for its spiritual dimension. One should pay particular attention 
to: the link between the sacrum and profanum, the history of a given place and its meaning, the religious origin of a place, the attributes of an object that is worshipped, the symbolism of a nurturing spring, the symbolism of trees and forms of greenery, the symbolism of digits, numbers and colours, the role of small architecture forms.

Designing the areas near sacral objects is a challenge for a landscaper, who has to combine functional aspects of the sacral space arrangement with historically-determined beliefs in the symbolic meaning of garden elements. Emphasising the features of a given object in a sacral space requires deep insight and understanding of the nature of worship and features of the place to be designed through the prism of its religious significance.

\section{THE ARTICLE IN ORIGINAL LANGUAGE}

\section{Wprowadzenie}

Chrześcijaństwo przejmuje zarówno lokalne kulty, jak i symbolikę biblijną, ale także większość archetypicznych pojęć od judaizmu. Choćby pojęcie Ziemi Świętej, które jest związane ze znaczeniem świętej przestrzeni czy sacrum wyrażonego poprzez zjawiska i siły przyrody. Zielony gaj lub ogród służy wartościom duchowym, modlitwie i kontemplacji. Jednym z najważniejszych czynników kształtujących stosunek człowieka do świata przyrody był mit biblijnego raju wypływający z kultu chrześcijańskiego. Liczne wizerunki ogrodu stanowią tło scen i wyobrażeń z życia Maryi, Jezusa i świętych, którym przypisano drzewa i kwiaty jako atrybuty i ornamenty. Samo drzewo zyskuje również nowy uniwersalny wymiar krzyża, jako Drzewa Zbawienia [17, str. 102-109]. Symbolicznie przedstawiano biblijne źródło, którego odpowiednikiem była studnia lub fontanna usytuowana na zbiegu ścieżek rozmieszczonych w ogrodzie na planie kwadratu otoczonym murami. Cztery boki symbolizowały rzeki Edenu, także ewangelistów i cnoty kardynalne, jak: roztropność, wstrzemięźliwość, sprawiedliwość i męstwo [10, str. 112-229; 13, str. 109-119].

Celem artykułu było zwrócenie uwagi na potrzebę uwzględnienia uwarunkowań historycznych i symbolicznego wymiaru elementów przestrzeni sakralnej w kreowaniu terenów zieleni przy obiektach kultu religijnego.

\section{Symbolika przestrzeni sakralnej}

Człowiek jako istota wyróżniająca się bogactwem przeżyć wewnętrznych potrzebuje symboli, aby przybliżyć sobie wszystko, co duchowe. Czasami mgliste odczuwanie ich bogatej treści może mu powiedzieć więcej niż słowa. Symbole bowiem łączą różne rzeczy w jedno ogólne wrażenie, natomiast mowa tylko w sposób cząstkowy i stopniowy uświadamia to, co przedstawiają symbole. Chrześcijanie z pierwszych wieków znali symbole tak dobrze jak alfabet, a prawdopodobnie nawet lepiej, ponieważ nie wszyscy umieli czytać. Stąd Ojcowie Kościoła głosząc kazania do ludu, czerpali przykłady ze świata symboli [5, str. 7-192].

Dzięki cechom symbolicznym, estetycznym i żywicielskim oraz zakreśleniu granic ogród sakralny jest przestrzenią szczególną i wybraną. Jako układ zamknięty, posiada bramy łączące to, co boskie - sacrum ze światem zewnętrznym - profanum. Bywa modelem kosmosu, odwzorowaniem dzieła stworzenia. W ujęciu współczesnym ogród jest najwyższym osiągnięciem cywilizacji, gdzie efekt ludzkiej myśli i zaplanowanego porządku łączy się z przyrodą. Można stwierdzić, że ogród sakralny to dzieło najwyższej doskonałości w rozumieniu harmonijnego współistnienia natury i kultury. Do najbardziej wymownych symboli chrześcijańskich należy krzyż - znak Męki Pańskiej, stąd często rzuty założeń sakralnych odnoszą się do tej symboliki. Ważny pod względem znaczeniowym jest kształt ryby nawiązujący do cudu rozmnożenia pokarmów przez Jezusa. Równie istotne $\mathrm{w}$ chrześcijaństwie są alfa $\mathrm{i}$ omega - symbole początku i końca [15, str. 58-63]. 
Nieocenione wartości wniósł do religii i całej ludzkiej kultury świat kompozycji roślinnych. Zarówno pierwotne wierzenia politeistyczne, jak i ukształtowane później religie, w tym islam i chrześcijaństwo, w podobny sposób przedstawiają wieczystą nagrodę. Są nią wspaniałe ogrody, obfitujące we wszystko, co jest cenione na ziemi - krainy piękna, szczęścia i zaspokojonych marzeń oraz pragnień „Zaprawdę, ci którzy się boją Boga, będą w Ogrodach i szczęśliwości..." [11, str. 29]. Należy pamiętać, że roślinności towarzyszą elementy nieożywione, z których wiele ma również wymiar symboliczny, jak np. woda, drewno czy skały lub zgrupowania kamieni. W przestrzeni o znaczeniu sakralnym mamy do czynienia $\mathrm{z}$ rozbudowaną oprawą symboliczną, bogactwem znaczeń i fascynacją, jaką budzą moc i zdolność do cyklicznego odradzania się natury [13, str. 109-119].

\section{Symbolika religijna przez pryzmat historii}

Przestrzeń sakralna jest odzwierciedleniem boskiego raju. W religiach opartych na Biblii pierwszym ogrodem był Eden - kraina wiecznej szczęśliwości, z której wygnani zostali prarodzice Adam i Ewa. U podstaw wyobrażeń o rajskim ogrodzie znajduje się sztuka ogrodowa rozumiana jako niezwykła mozaika zapachów, dźwięków i światła, która zrodziła się z ludzkich pragnień poznania tajemnic stworzenia. Wynikała z ciągłych prób odtworzenia ogrodu, choćby po części dorównującego dziełu Stwórcy. Biblijna wizja raju, wykorzystywana w założeniach ogrodowych, była modelem kosmosu, uznawanym za metaforę doskonałego życia duchowego. Obraz wszechświata jako „ziemskiego raju” podzielony był czterema rzekami: Gihon, Physon, Tygrys i Eufrat, rozchodzącymi się na różne strony świata. Centralną część odtwarzanego raju zajmowało ożywcze źródło. Całość tworzyła swoiste pole magiczne, wypełnione figurami i symbolami, wskazujące drogę duchową do boskich tajemnic [13, str. 109-119; 3, str. 17-18]. Przestrzeń sakralną można traktować jako „symbol porządku kosmicznego, odosobnienia, kontemplacji, niewinności” [2, str. 245].

Rajski ogród stał się wyrazem dążenia człowieka do przeciwstawienia się pierwotnej przyrodzie, pojmowanej jako chaos. W okresie średniowiecza zieleń aranżowano głównie jako ogrody klasztorne. Klasztory benedyktyńskie miały zapisany w swej regule zakonnej obowiązek posiadania ogrodu. Rozległa działalność zakonników wywarła duży wpływ na kształtowanie ogrodów i uprawę różnych roślin użytkowych i ozdobnych w całej Europie. W wielu klasztorach reguła zakonna przewidywała także uprawę roli i ogrodów. Ogrody klasztorne dzieliły się ze względu na przeznaczenie na użytkowe i ozdobne. Do pierwszej grupy należały ogrody: uprawne, lekarskie, szpitalne, cmentarne, natomiast do drugiej: wirydarz - stale powtarzający się składnik założeń klasztornych oraz ogród opata [8, str. 87-88; 18, str. 73-80].

Wirydarz wpisany w czworobok krużganków klasztornych miał geometryczny podział płaszczyzny oparty na obowiązującej w tym czasie zasadzie ad quadratum [16, str. 1-351]. Już w starożytności kwadrat był uważany za figurę doskonałą. W średniowieczu także pozostał figurą uprzywilejowaną, stosowano go często jako podstawowy moduł budowli. Kwadratura szybko przyjęła się jako podstawa rozplanowania ogrodów z uwagi na swoje walory praktyczne, nie tylko w założeniach klasztornych, ale także w ogrodach renesansu i baroku [9, str. 61-64; 10, str. 112-229].

Ogrody od najdawniejszych czasów są nieodłącznym elementem miejsc kultu. Początkowo miejsca poświęcone Bogu były otaczane pięknem dzikiej przyrody.

$\mathrm{Z}$ czasem jednak świątyniom towarzyszyły świadomie kształtowane kompozycje ogrodowe w różnej skali. Trendy ukształtowane w przeszłości, można odszukać również współcześnie. Kształtowana zieleń towarzyszy świątyniom i założeniom klasztornym, także sanktuariom, kalwariom, kapliczkom i krzyżom przydrożnym. Skala założeń ogrodowych w Polsce jest zróżnicowana i dostosowana do wielkości obiektu sakralnego. Wszystkie typy ogrodów sakralnych charakteryzuje wykorzystanie elementów ogrodowych w podwójnej roli: 
estetycznej i znaczeniowej, bazującej na symbolice chrześcijańskiej. Pomimo zróżnicowania regionalnego, ogrody sakralne mają trwałą i czytelną do dziś strukturę przestrzenną. Ta niezmienność struktury, wynikająca z nieprzemijającej tradycji, jest wyróżnikiem i znakiem tożsamościowym rodzimych krajobrazów [8, str. 87-88].

\section{Symbolika religijna drzewa}

Szczególnym symbolem w kulturze chrześcijańskiej jest drzewo, któremu nadaje się znaczenie elementu łączącego niebo i ziemię poprzez wyciągnięte $\mathrm{w}$ górę konary oraz zagłębione w gruncie korzenie. Pień drzewa oznacza egzystencję na ziemi, pomiędzy życiem podziemia a życiem niebiańskim. Drzewo jest również odzwierciedleniem odrodzenia i życia poprzez swój rozwój w ciągu roku. Zimozielone drzewa iglaste stanowią symbol życia i nieśmiertelności, natomiast drzewa zrzucające liście na okres zimy i powracające do życia wiosną są symbolem odrodzenia [4, str. 47].

Naturę i zjawiska przyrodnicze czczono już w czasach prehistorycznych. W kulturze babilońskiej i asyryjskiej pojawiły się święta góra i drzewo. Kult sił przyrody leży też u źródeł islamu, który m.in. w roślinach dopatrywał się dowodów działalności Boga. W każdym wyobrażeniu raju drzewo pełni ważną rolę. Liście rzucają życiodajny cień, spod korzeni bije czysta woda lub rzeki mleka i miodu. Zarówno w Starym, jak i Nowym Testamencie drzewa posiadają liczne znaczenia i rozbudowaną metaforykę. Również u starożytnych Żydów utrwalony był kult głazów, pagórków i drzew - dębów i terebintów, pod którymi składano ofiary. Grecy i Rzymianie łączyli poszczególne gatunki drzew z symboliką: oliwkę z dostatkiem, cyprys z żałobą, laur i dąb z mądrością i męstwem. Zanim zaczęli wznosić okazałe świątynie, ich miejsca kultu znajdowały się w świętych gajach [9, str. 61-64].

Obyczaj kultu drzew, stanowiących oś kosmosu i symbolizujących wieczność, dotyczy też plemion północy. W mitologii germańskiej spotyka się „drzewo wszechświata” o bardzo rozbudowanej funkcji. W konarach była siedziba bogów, pod korzeniami mroźna i ciemna kraina na kształt piekła. Słowianie także mieli swoje święte gaje, a w nich: dęby, lipy, klony, jesiony i wiązy. Celtowie czcili drzewa w gajach cisowych i dębowych, jako pierwsi tworzyli sanktuaria. Szczególne znaczenie miała jabłoń, często spotykana w literaturze i ikonografii. Do dzisiejszych czasów przetrwał uświadomiony i emocjonalny stosunek do drzew, a kościół czy cmentarz otoczony wieńcem starych lip jest stałym elementem polskiego krajobrazu. $\mathrm{Na}$ drzewach i pod drzewami są umieszczane kapliczki i figury wotywne. Często drzewo ze świętym obrazem jest ostatnim zachowanym reliktem alei, parku czy przydrożnego pasa izolacyjnego [17, str. 102-109].

\section{Symbolika religijna roślin}

Chrześcijańska symbolika roślin dotyczy zarówno poszczególnych gatunków, jak i ich kolorystyki (tab. 1). Uprzywilejowaną barwą często przywoływaną w symbolice ogrodu, obok zieleni, jest czerwień. Barwy róży, krwi, soku czy wina to kolory życia i śmierci, ekstazy i zapomnienia. Czerwona róża pośród cierni, o barwie przypominającej krew, jest atrybutem męczenników i symbolem męki Chrystusa. Biała róża bez kolców wyobraża cnoty Maryi, jej niepokalane poczęcie i dziewictwo. Maur porównywał narodziny Chrystusa z dziewicy do róż rozkwitających na ciernistym krzewie, a Dante ogląda Maryję jako Różę mistyczną [5, str. 7192; 20, str. 143-144].

Pośród kwiatów, które jako symbole pór roku są uosobieniem wiosny, róża zajmuje - ze względu na swe piękno i zapach - czołowe miejsce. Grecy wywodzili jej nazwę od „płynąć, rozlewać", bowiem rozlewają się od niej strumienie woni, tym samym jednak ulatnia się jej żywotna substancja i dlatego tak szybko więdnie. Starożytni byli pod wrażeniem zarówno przepychu róży, jak i jej krótkiego życia. Pliniusz Starszy napisał: „Kwiaty i zapachy natura zrodziła na krótki okres; powinno to być przestrogą dla ludzi, że to, co przepięknie kwitnie (tj. 
róże, lilie, fiołki), szybko też więdnie". Pismo Święte wymienia różę pośród aromatycznych roślin, z którymi porównuje się wieczną mądrość. Według Księgi Mądrości Syracha, dzieci Boże mają kwitnąć jak róża. Ciernie róży także mają symboliczne znaczenie, ponieważ wyobrażają grzechy i ich skutki, ból i cierpienie. Ciernie oplatają skroń cierpiącego Zbawiciela „...pośród cierni zepsucia jaśnieje wolna od cierni dziewiczość”. Prawdziwą „różą wśród cierni” jest Niepokalana Dziewica Maryja [12, str. 64-71; 19, str. 57-58].

Rozpowszechniona jest maryjna symbolika lilii, która jest nieodłącznym atrybutem scen zwiastowania symbolizującym dziewictwo Maryi - trzy lilie to znak potrójnego dziewictwa: przed, w momencie i po narodzeniu Chrystusa [5, str. 7-192]. W Palestynie lilię można znaleźć wśród krzaków ciernistych, pośród których bujnie się rozwija. Z lilią jest utożsamiana Maryja Niepokalanie Poczęta, która zakwitła pośród ostów i cierni grzesznego rodzaju ludzkiego. Chrystus sam nawołuje w Ewangelii do podziwiania kwiatów „Przypatrzcie się liliom na polu, jak rosną (...), nawet Salomon w całym swoim przepychu nie był tak ubrany jako jedna z nich" [Mateusz, 6, 28, Nowy Testament - 1, str. 592-1433]. Kwiaty jako ozdoba kościołów od najdawniejszych czasów są niemym hołdem składanym Bogu. Róże i lilie należały do darów, które wolno było składać w czasie procesji wokół ołtarza podczas ofiarowania [5, str. 7-192].

Roślinność, którą ozdabiano kapliczki i krzyże, była sadzona zgodnie z lokalnymi tradycjami. Stąd przy kościołach, świętych figurach czy na cmentarzu można odszukać różnorodne gatunki roślin. Często są tu sadzone cisy, żywotniki, bluszcz, będące nie tylko ozdobą, ale również wyrazem wiary w życie wieczne. Powszechnie stosowane są rośliny związane z kultem Matki Boskiej jak lilia biała (Lilium candidum L.), irysy (Iris sp.), róże (Rosa sp.). Kapliczki, jak i krzyże często stawiano w bezpośrednim sąsiedztwie drzew, które są silnie związane z tradycją chrześcijańską, oznaczając więź nieba z ziemią. Zieleń wysoka o znaczeniu sakralnym jest reprezentowana przez drzewa, które są silnie zakorzenione $\mathrm{w}$ tradycji ludowej $\mathrm{i}$ często były postrzegane przez pryzmat wierzeń. Obdarzanie ich czcią religijną w wielu regionach naszego kraju jest pozostałością słowiańskiego kultu drzew. Dotyczy to głównie drzew, które konarami otaczały świątynie, ocieniały groby, kaplice, kapliczki, figury, obrazy świętych, krzyże przydrożne i święte źródła [20, str. 143-144].

Szczególnie czczone były drzewa, na których miała ukazać się ludowi Matka Boża lub święty. Była to zazwyczaj lipa (Tilia sp.), uznawana powszechnie za drzewo opiekuńcze. Inne często stosowane gatunki drzew to: klon (Acer sp.), w tym jawor (Acer pseudoplatanus L.) chroniące przed nieszczęściem, jesion (Fraxinus sp.) i głogi (Crataegus sp.) - zapewniające pokój i sprawiedliwość, dostatek i zdrowie, oraz dąb (Quercus sp.) - od najdawniejszych czasów symbol mocy, trwałości i siły [8, str. 87-88].

Wybrane rośliny symboliczne do zastosowania w przestrzeni sakralnej Tabela 1 - Table 1 Selected symbolic plants for use in sacred space

\begin{tabular}{|l|c|l|}
\hline \multicolumn{1}{|c|}{ Roślina } & $\begin{array}{c}\text { Nr strony w } \\
\text { leksykonie* }\end{array}$ & \multicolumn{1}{c|}{ Znaczenie sakralne } \\
\hline Bluszcz & $(50)$ & $\begin{array}{l}\text { symbol wiecznego życia i wierności - silnie łączy się ze } \\
\text { swoim podłożem }\end{array}$ \\
\hline Bratek & $(54)$ & roślina lecznicza, nazywana kwiatem Trójcy św. \\
\hline Cedr & $(58)$ & $\begin{array}{l}\text { roślina wiecznie zielona, symbol raju i życia wiecznego, a w } \\
\text { Starym Testamencie również siły i piękności }\end{array}$ \\
\hline Cyprys & $(69)$ & $\begin{array}{l}\text { symbol raju i życia wiecznego, wg Syracha jest symbolem } \\
\text { mądrości i ludzi wybranych (także Maryi), w Polsce symbol }\end{array}$ \\
\hline
\end{tabular}




\begin{tabular}{|c|c|c|}
\hline Roślina & $\begin{array}{l}\text { Nr strony w } \\
\text { leksykonie** }\end{array}$ & Znaczenie sakralne \\
\hline & & żałoby i śmierci \\
\hline Cytryna & $(69)$ & $\begin{array}{l}\text { symbolizuje życie i urodzaj, stosowana podczas ślubów, } \\
\text { chrztów i pogrzebów }\end{array}$ \\
\hline Dąb & (76) & $\begin{array}{l}\text { święte drzewo Germanów, oznacza siłę i życie wieczne } \\
\text { (twarde drewno, nie ulegające rozkładowi) }\end{array}$ \\
\hline Drzewo oliwne & $(84)$ & $\begin{array}{l}\text { symbolizuje życie wieczne, niepokalaną i uzdrawiającą łaskę } \\
\text { Matki Boskiej }\end{array}$ \\
\hline Dynia & $(85)$ & oznacza nietrwałość ludzkiego życia \\
\hline Fiołek & $(103)$ & $\begin{array}{l}\text { utożsamiana z pokorą Maryi, kolor wskazuje na mękę pańską } \\
\text { i niebiańskie Królestwo Chrystusa }\end{array}$ \\
\hline Fiołek alpejski & $(104)$ & $\begin{array}{l}\text { roślina maryjna, barwa czerwona w środku kwiatu odnosi się } \\
\text { do serca Maryi krwawiącego z bólu }\end{array}$ \\
\hline Goździk & $(113)$ & $\begin{array}{l}\text { przybył w XIII w. z krzyżowcami, kwiat krwistoczerwony to } \\
\text { symbol pasyjny, liście i kwiaty - mające kształt gwoździ - } \\
\text { wskazują na przyszłą śmierć Chrystusa na krzyżu }\end{array}$ \\
\hline Irys & $(124)$ & $\begin{array}{l}\text { roślina maryjna, z gr. oznacza tęczę, symbolizuje pojednanie } \\
\text { ludzi z Bogiem, przymierze odnowione przez ofiarną śmierć } \\
\text { Chrystusa }\end{array}$ \\
\hline Klon & $(145)$ & drzewo zapewniające ochronę przed nieszczęściem \\
\hline Koniczyna & $(157)$ & odniesienie do Trójcy św. \\
\hline Konwalia & $(158)$ & $\begin{array}{l}\text { z łac. lilia doliny, zapach i kolor kwiatu są utożsamiane z } \\
\text { łagodnością i dziewiczą czystością Maryi }\end{array}$ \\
\hline $\begin{array}{l}\text { Kuklik } \\
\text { pospolity }\end{array}$ & $(170-171)$ & $\begin{array}{l}\text { żółto kwitnący jest stosowany jako roślina lecznicza, } \\
\text { wskazuje na Chrystusa jako Zbawiciela świata } \\
\end{array}$ \\
\hline Lilia & $(177-178)$ & $\begin{array}{l}\text { w rejonach Morza Śródziemnego była symbolem światła i } \\
\text { życia, w powszechnym znaczeniu oznacza ufność w łaskę } \\
\text { Bożą, władzę duchowną, czerwone kwiaty wskazują na Mękę } \\
\text { Pańską, kwiaty białe to dziewicza czystość i niewinność, } \\
\text { atrybut Maryi }\end{array}$ \\
\hline Lipa & $(180)$ & uznawana za drzewo opiekuńcze \\
\hline Malwa & $(186)$ & symbol uzdrowicielskiej mocy Maryi \\
\hline Margerytka & $(189)$ & $\begin{array}{l}\text { oznacza perłę, symbol przelanych łez, wskazuje na cierpienie } \\
\text { Chrystusa i męczenników }\end{array}$ \\
\hline Migdałowiec & $(203)$ & kwitnący wiosną symbol czujności Boga \\
\hline Nagietek & $(213)$ & $\begin{array}{l}\text { z niem. oblubieniec słońca, znak uzdrowicielskiej mocy } \\
\text { Maryi }\end{array}$ \\
\hline Narcyz & $(215-216)$ & $\begin{array}{l}\text { symbol mistycznej oblubienicy (razem z lilią i konwalią), } \\
\text { oznacza także Zmartwychwstanie }\end{array}$ \\
\hline Orlik & $(237)$ & $\begin{array}{l}\text { roślina lecznicza, symbolizująca płodność, } 7 \text { kwiatów } \\
\text { odczytywane jako } 7 \text { darów Ducha św., liście nawiązujące do } \\
\text { ptaków - gołębic, także odnoszone do Ducha Św. }\end{array}$ \\
\hline Orzech & $(237-238)$ & $\begin{array}{l}\text { symbolizuje Chrystusa, gorzka zielona powłoka oznacza } \\
\text { cierpienie Jezusa na ziemi, drewniana skorupka wskazuje na } \\
\text { drzewo Krzyża, słodki owoc na Boską naturę - dającą życie, }\end{array}$ \\
\hline
\end{tabular}




\begin{tabular}{|c|c|c|}
\hline Roślina & $\begin{array}{l}\text { Nr strony w } \\
\text { leksykonie* }\end{array}$ & Znaczenie sakralne \\
\hline & & również symbol urodzajności i płodności \\
\hline Ostróżka & $(239-240)$ & $\begin{array}{l}\text { symbol szlachty i rycerstwa, pomaga na bóle oczu, stąd } \\
\text { odniesienie do wyzwolenia od duchowej ślepoty za sprawą } \\
\text { Chrystusa i Maryi }\end{array}$ \\
\hline Osty i ciernie & $(240)$ & uciążliwy chwast, początkowo symbol grzechu i trudu \\
\hline Pierwiosnek & $(251)$ & $\begin{array}{l}\text { stara roślina lecznicza, wyrósł tam, gdzie św. Piotr upuścił } \\
\text { klucz do niebios, także symbol Matki Boskiej, która przez } \\
\text { swojego Boskiego Syna otwiera niebo dla ludzi }\end{array}$ \\
\hline Sosna pinia & $(253)$ & symbolizuje życie i żyzność \\
\hline Przebiśnieg & $(262)$ & $\begin{array}{l}\text { symbol nadziei, atrybut Matki Boskiej, źródła wszelkiej } \\
\text { nadziei chrześcijańskiej }\end{array}$ \\
\hline Róża & $(277-278)$ & $\begin{array}{l}\text { kwiaty czerwone - symbol męczeństwa krwawego świętych, } \\
\text { białe - kwiaty Maryi }\end{array}$ \\
\hline Rumianek & $(279-280)$ & roślina lecznicza oznacza uzdrowicielską moc Maryi \\
\hline Skalnica & $(293)$ & $\begin{array}{l}\text { w średniowieczu wierzono, że rosnąca w skalnych } \\
\text { szczelinach potrafi rozsadzić kamienie - odnoszono ją do } \\
\text { Zmartwychwstania Chrystusa z zamkniętego grobu }\end{array}$ \\
\hline Słonecznik & (294) & symbol duszy, która kieruje się ku Bogu \\
\hline Stokrotka & $(299)$ & $\begin{array}{l}\text { według legendy wyrosła z łez przelanych prze Maryję w } \\
\text { czasie ucieczki do Egiptu }\end{array}$ \\
\hline Szałwia & $(309)$ & roślina lecznicza, utożsamiana z uzdrowicielską mocą Maryi \\
\hline Tulipan & $(347)$ & $\begin{array}{l}\text { symbolizuje próżność, marność i znikomość wszystkich } \\
\text { rzeczy doczesnych, symbol śmierci }\end{array}$ \\
\hline Wierzba & $(355)$ & $\begin{array}{l}\text { gałązki wykorzystywane w obrzędach religijnych, żywotna } \\
\text { roślina, podcinana wypuszcza nowe pędy - symbol } \\
\text { Ewangelii, której przesłanie pozostaje zawsze aktualne, bez } \\
\text { względu na to, w którym zakątku ziemi jest głoszona }\end{array}$ \\
\hline Krzew winny & $(357-358)$ & symbol Kościoła i Chrystusa \\
\hline Zawilec & $(372)$ & $\begin{array}{l}\text { kwiat szybko więdnący, symbolizuje śmierć (miłek } \\
\text { wiosenny), symbol krwi męczenników i cierpienia Chrystusa }\end{array}$ \\
\hline
\end{tabular}

* Źródto: [22] Siebiert J. 2007. Leksykon sztuki chrześcijańskiej. Tematy, postacie, symbole. Wyd. Jedność, Kielce.

\section{Symbolika religijna cyfr, liczb i barw}

W symbolice chrześcijańskiej wyraźny przekaz niosą cyfry, liczby i barwy. Szczególne znaczenie dla chrześcijan mają takie cyfry i liczby, jak: 3, 4, 5, 6, 7, 12. Już starożytne mitologie przedstawiały triady boskie (egipska Ozyrys - Izyda - Horus, babilońska Sin - Szamasz Isztar), a cyfra „trzy” od zawsze wyrażała uniwersalność, doskonałość i pełnię. W Biblii „trzy” oznacza po trzykroć świętego Boga (trzy Osoby Boskie), odnosi się do cnót boskich - wiary, nadziei i miłości oraz Zmartwychwstania Pańskiego po trzech dniach i nocach. Cyfra ta ma także negatywne znaczenie - Szatan trzykrotni kusi Jezusa na pustyni, Piotr trzy razy wypiera się Chrystusa, trzy dni trwały ciemności egipskie [1, str. 592-1433]. W ogólnym zarysie cyfrę „trzy” można uznać za symbol wszystkiego, co boskie (sacrum). 
Cyfra „cztery” wyraża istotę kosmicznej całości - strony świata, główne wiatry i pory roku występują czterokrotnie. W Edenie strumień rozdziela się na cztery rajskie rzeki, a w Apokalipsie tronu Bożego strzegą cztery zwierzęta, symbolizujące cały świat stworzony przez Boga. Wyraźny jest przekaz tej cyfry w postaci Ewangelistów, jeźdźców Apokalipsy i podziale cnót kardynalnych (sprawiedliwość, męstwo, roztropność i umiarkowanie). Nawet imię pierwszego człowieka składa się z czterech liter, a każda $\mathrm{z}$ tych liter jest początkiem nazw stron świata w języku greckim - Anatole, Dysis, Arktos i Mesembria [7, str. 25-270]. Można przyjąć zatem, że cyfra „cztery” symbolizuje to, co ziemskie (profanum).

Suma liczb „trzy” i „cztery” wynosi „siedem”, które w chrześcijaństwie jest wyrazem całości (połączenie tego co boskie - duszy ludzkiej z ziemskim ciałem człowieka, także połączenie cnót). Siódmego dnia Bóg odpoczywał po stworzeniu świata, siedem dni Noe czekał na powrót gołębia, Modlitwa Pańska zawiera siedem próśb, było siedem lat i krów tłustych i tyle samo chudych, wreszcie jest siedem sakramentów świętych i tyle samo grzechów głównych. Cyfra „siedem” symbolizuje jedność dwóch światów, jest ich połączeniem i ma wyraz skończenia [1, str. 592-1433].

Istoty nieprzyjazne Bogu miały swoje numeryczne imię, którego symbolem było „sześć” i wielokrotność tej cyfry. Domniemywa się również, że tą cyfrą określano także Nerona - wroga chrześcijan. Liczba „dwanaście” (przenikanie liczb „trzy” i „cztery”) kojarzona głównie z Apostołami, którzy są filarem Kościoła chrześcijańskiego. W Starym Testamencie jest mowa o dwunastu pokoleniach Jakuba, którzy stali się początkiem narodu izraelskiego, dwunastu zwiadowców wysłano do ziemi obiecanej, a tyleż byków podtrzymywało „morze” spiżowe [7, str. 25-270]. Apokalipsa św. Jana również przywołuje kosmiczne znaczenie tej liczby „Niewiasta ma na głowie wieniec z gwiazd dwunastu” [Ap 12,1 - 1, str. 592-1433] jako odzwierciedlenie zwierząt ze znaków Zodiaku, a wokół tronu zgromadzili się starcy po dwunastu $\mathrm{z}$ każdej strony. Ponadto symboliczna jest sto czterdzieści cztery tysiące oznaczająca zbawionych, z każdego pokolenia izraelskiego po dwanaście tysięcy wybranych [1, str. 5921433].

Istotna jest wymowa barw w religii chrześcijańskiej, które określają różne przymioty świętych i Boga, co można zaobserwować również w użyciu ornatów podczas uroczystości kościelnych. Biel symbolizuje czystość i niewinność Maryi oraz zbawienie świata przez Chrystusa, błękit - niebiańskość i wieczność, czerwień - męczeństwo Chrystusa (purpurowy był płaszcz zarzucony na Jego ramiona po biczowaniu), ale także gniew i gwałtowne uczucia, fiolet - pokorę, jak i godność oraz autorytet, srebro - oczyszczenie, sprawiedliwość i czyste sumienie (św. Anna, matka Maryi jest nazywana matką srebra i jest patronką kopalni tego kruszcu), złoto - wewnętrzne bogactwo, oraz to, co ziemskie i przemijające [7, str. 25-270].

\section{Mała architektura sakralna}

Obiektami o szczególnej wymowie w krajobrazie są krzyże, figury świętych i kapliczki. Do najcenniejszych należą stare, tradycyjne kapliczki z piętnem upływającego czasu wyrytym w słojach drewna czy kamieniu, przycupnięte gdzieś pod wiekowym drzewem lub wznoszące się majestatycznie na tle zieleni łąk w otoczeniu barwnych kompozycji z naturalnych kwiatów. Ich obecność jest wyrazem potrzeb duchowych człowieka, a także wiary minionych pokoleń. Na terenie całej Polski często spotyka się je w otoczeniu przyrody. Forma kapliczki inspirowana była m.in. tradycjami rodzimej architektury. Budowano je z drewna, cegły, zdobiąc daszkiem z dachówek lub blachy, czasami tynkowano i malowano farbą. Kapliczki i krzyże najczęściej są otaczane niewielkim sztachetowym płotkiem, który podkreśla wyjątkowość miejsca. Wnętrze małego ogródka jest wypełnione roślinami związanymi z symboliką chrześcijańską. Wokół krzyża najwyższe piętro roślin stanowią często krzewy lilaka pospolitego (Syringa vulgaris L.) i róży pomarszczonej (Rosa rugosa THUNB.), a także słoneczniki (Helianthus sp.), malwy (Alcea 
sp.), niższe rośliny to rudbekie (Rudbeckia sp.), kosaćce (Iris sp.), liliowce (Hemerocallis sp.), nasturcje (Tropaeolum sp.) [8, str. 87-88; 15, str. 58-63].

\section{Symbole w historii sanktuariów maryjnych Archidiecezji Warmińskiej}

Historia sanktuariów Archidiecezji Warmińskiej, wskazuje na ogromne znaczenie sił natury i symboliki drzew w kształtowaniu miejsc kultu maryjnego. Świadomość wartości tych obiektów pozwala spojrzeć głębiej na istotę projektowania nowo powstających obiektów, z uwzględnieniem złożonej symboliki chrześcijańskiej.

\section{Gietrzwałd - Sanktuarium Matki Bożej Gietrzwałdzkiej}

Historia gietrzwałdzkiego kościoła sięga początku XIV w. (ryc. 1). Obecna świątynia powstała na przełomie XV i XVI w. i rozbudowana została w XIX w. Jej wyposażenie jest neogotyckie, a styl eklektyczny. Od 1970 r. posiada godność bazyliki mniejszej. W dziejach sanktuarium splatają się dwa elementy: łaskami słynący obraz oraz XIX-wieczne objawienia Matki Bożej. Od 27 czerwca do 16 września 1877 r. Matka Boża ukazywała się dwóm dziewczynkom - trzynastoletniej Justynie Szafryńskiej i dwunastoletniej Barbarze Samulowskiej. Przemówiła do nich w języku polskim, ukazując się nad nieistniejącym już dzisiaj przykościelnym klonie. Wizjonerki rozpowszechniły także kult maryjny, wskazując źródełko pobłogosławione przez Matkę Boską. Objawienia spowodowały napływ pielgrzymów, a także prześladowania wiernych i księży z Gietrzwałdu przez zaborców. W miejscu, gdzie dzieciom ukazywała się Matka Boża, powstała kapliczka z figurą Najświętszej Marii Panny z upamiętniającym wydarzenie fragmentem drewna $z$ klonu. Wymiar symboliczny mają także aleja różańcowa prowadząca do źródełka i malownicza droga krzyżowa na skraju lasu [21c, dostęp 2015-01-23].

\section{Kẹtrzyn - Sanktuarium Najświętszej Maryi Panny, Matki Miłosierdzia}

Do szerzenia kultu maryjnego w duchu ostrobramskim na ziemi kętrzyńskiej przyczynili się kapłani pracujący w parafii św. Jerzego, urodzeni lub wykształceni w Wilnie. Pochodzący z 1359 r. kościół, przypominający w całym kompleksie zamek, od wieków kształtuje panoramę grodu. Jest klasycznym typem średniowiecznego kościoła obronnego. W 1515 r. mistrz Matz z Gdańska zwieńczył ją kryształowym sklepieniem. W latach 1525-1946 kościół służył protestantom, potem powrócił w posiadanie katolików. W podziemiach kościoła było krzyżackie więzienie, tutaj według podań, przebywał skazaniec, któremu objawiła się Maryja i poprosiła, by wyrzeźbił Jej figurkę. Krzyżacy, uznając to wydarzenie za nadprzyrodzone zjawisko, wypuścili więźnia, który idąc w kierunku Reszla, zawiesił figurkę Madonny na przydrożnej lipie. Miejsce, które wkrótce zasłynęło cudami i uzdrowieniami, dało początek sanktuarium w Świętej Lipce [21a, dostęp 2015-03-03].

\section{Świêta Lipka - Sanktuarium Matki Bożej Świętolipskiej}

Świętolipskie sanktuarium maryjne zwane jest „Częstochową Północy” (ryc. 2), a historia tego miejsca sięga XIV w. W miejscu, gdzie ocalony skazaniec z Kętrzyna powiesił figurkę Matki Boskiej na drzewie zbudowano kaplicę o wymiarach 8x12m, z której przez otwór w dachu wystawała lipa. Według dokumentów z XV w., sława sanktuarium wykraczała poza granice diecezji. Pomimo zburzenia w 1524 r., położenia na terytorium protestanckim, zakazu pielgrzymek i kultu maryjnego, napływ pielgrzymów trwał nadal. Święta Lipka od czasów reformacji jest miejscem pielgrzymowania, również dla ewangelików. Papież Jan Paweł II nadał kościołowi w 1983 r. tytuł bazyliki mniejszej [21e, dostęp 2015-02-09].

Stoczek Klasztorny - Sanktuarium Matki Pokoju

Kościół jest barokową z 1671 r., murowaną budowlą w kształcie rotundy z wieżą. Wyposażenie kościoła pochodzi z XVIII w. Powstał w miejscu dawnej kapliczki upamiętniającej odkrycie przez dwie dziewczynki figurki Matki Bożej w pniu starego dębu, jednak jego powstanie $\mathrm{w}$ obecnej formie było związane $\mathrm{z}$ sytuacją polityczną po okupacji szwedzkiej. 
Powojenne dzieje sanktuarium są związane z uwięzieniem prymasa Polski, Stefana kardynała Wyszyńskiego. Przebywał w murach tego klasztoru od 12 października 1953 do 6 października 1954 r., w tym czasie dokonał on aktu duchowego oddania się Matce Bożej. 9 maja 1987 r. papież Jan Paweł II nadał kościołowi w Stoczku tytuł bazyliki mniejszej. Od 1957 r. opiekę nad sanktuarium sprawują księża marianie [21d, dostęp 2015-02-23].

\section{Olsztyn - Sanktuarium Matki Boskiej Fatimskiej}

Parafia pod wezwaniem Matki Boskiej Fatimskiej w Olsztynie powstała w 1995 r. (ryc. 3). Wysunięty na dalekie obrzeża miasta kościół o strzelistej formie pełni ważną rolę w rozwoju duchowym mieszkańców pobliskich osiedli. Korzenie kultu maryjnego sięgają Fatimy, w której w 1917 r. miały miejsce jej objawienia nad świętym dębem, stąd szczególnego znaczenia nabiera w tej przestrzeni symbolika drzewa. Miejscowość ta usytuowana w środkowej Portugalii, około $130 \mathrm{~km}$ od stolicy Lizbony, na południowy wschód od miasta Leiria, jest obecnie światowym ośrodkiem pielgrzymkowym. Matka Boża poleciła tutaj trojgu dzieciom - pastuszkom (Łucji, Franciszkowi i Hiacyncie) odmawianie różańca oraz wybudowanie ku Jej czci kaplicy. Początkowo obok dębu, nad którym miało miejsce objawienie, postawiono drewnianą bramę, przy której modlili się wierni. Następnie 28 kwietnia 1919 r. wybudowano tymczasową kaplicę. 13 października 1930 r. biskup Leirii uznał wiarygodność objawień fatimskich i zezwolił na oficjalny, lokalny kult Matki Bożej Różańcowej w Fatimie. 13 maja 1953 r. patriarcha Lizbony kardynał Manuel Cerjeira poświęcił nową świątynię, którą budowano w latach 1928-1953 na planie łacińskiego krzyża z 14 kaplicami, które wraz z prezbiterium miały symbolizować tajemnice różańca. Świątynia została konsekrowana 7 października 1953 r., od 1954 r. nosi tytuł bazyliki [6, str. 20]. W parafii olsztyńskiej każdego 13 dnia miesiąca, od maja do października, odbywają się nabożeństwa ku czci Matki Bożej Fatimskiej. Składają się na nie: Litania Loretańska, Msza św., Różaniec Fatimski z procesją do pięciu tajemnic różańcowych na zewnątrz kaplicy oraz czuwanie adoracyjne przed Najświętszym Sakramentem [21b, dostęp 2015-07-09]. Nabożeństwa fatimskie wychodzą poza mury budynku kościoła i w uroczystej formie są kontynuowane w przestrzeni sakralnej. W otoczeniu sanktuarium w Olsztynie wciąż aktualna jest potrzeba ukazania rangi historycznych objawień poprzez wykorzystanie symbolicznego znaczenia zieleni.

\section{Podsumowanie}

Znamienite przykłady miejsc kultu religijnego, w tym znajdujące się na terenie Warmii, swoją genezą potwierdzają silne związki wydarzeń religijnych $\mathrm{z}$ otoczeniem przyrodniczym. Przegląd historii powstania sanktuariów warmińskich wskazuje na szczególną rolę drzewa w przestrzeni sakralnej. Do uprzywilejowanych gatunków należą dąb (Quercus sp.), lipa (Tilia sp.), klon (Acer sp.). Warto kontynuować kult objawień poprzez wprowadzanie na terenach przykościelnych zieleni wysokiej i roślin kwiatowych. Dobór gatunków roślin powinien bazować na rodzimej roślinności. Uzupełnieniem całości mogą być wszystkie elementy, których znaczenie $\mathrm{w}$ chrześcijaństwie zostało ugruntowane ze względu na przesłanki religijne, uwarunkowania historyczne i lokalne tradycje (np. krzyż, brama, źródło). Wymowę symboliczną mają również zestawienia tych elementów w grupy i barwne kompozycje, a także rodzaj zastosowanego materiału (woda, drewno, skały).

Przestrzeń sakralna, jako miejsce szczególne $\mathrm{z}$ uwagi na możliwość pojednania duchowego z Bogiem, wymaga dużej dbałości o jej wymiar duchowy. W kreowaniu tej przestrzeni warto zwrócić uwagę przede wszystkim na: powiązanie sacrum i profanum, znaczenie historii miejsca, religijną genezę obiektu, atrybuty przedmiotu kultu, symbolikę ożywczego źródła, symbolikę drzewa i form zieleni, symbolikę cyfr, liczb i barw, rolę małej architektury. 
Projektowanie terenów przy obiektach sakralnych jest dużym wyzwaniem dla architekta krajobrazu. Musi on powiązać funkcjonalność zagospodarowania przestrzeni sakralnej z historycznie ukształtowanymi przekonaniami o symbolicznym wymiarze elementów ogrodowych. Wyeksponowanie cech konkretnego obiektu w przestrzeni sakralnej wymaga głębokiego zrozumienia istoty kultu i uwarunkowań projektowanego miejsca przez pryzmat jego znaczenia religijnego.

\section{Bibliography}

1. Biblia Tysiąclecia, Pismo Święte Starego i Nowego Testamentu, Poznań, Pallotinum, 2003, p. 592-1433.

2. Biedermann H., Leksykon symboli, Warszawa, Muza SA, 2001, p. 245.

3. Bogdanowski J., Ogrody Polskie, Warszawa, Arkady, 1978, p. 17-18.

4. Chenel A.P., Simarro A.S., Stownik symboli, Warszawa, Świat Książki, 2008, p. 47.

5. Forstner D., Świat symboliki chrześcijañskiej, Warszawa, Instytut Wyd. Pax, 1990, p. 7-192.

6. Gałązka G., Moje Niepokalane Serce zwycięży, Marki, Wyd. Michalineum, 2000, p. 20.

7. Lurker M., Słownik obrazów i symboli biblijnych, Poznań, Pallotinum,1989, p. 25-270.

8. Majdecka-Strzeżek A., Zieleń obiektów sakralnych $w$ Polsce - tradycja $i$ wspótczesność, Warszawa, SGGW, 2003, p. 87-88.

9. Majdecki L., Historia ogrodów. Przemiany formy i konserwacja, Warszawa, PWN, 1981, p. 6164.

10. Majdecki L., Historia ogrodów. Od starożytności po barok, Tom 1, Warszawa, PWN, 2008, p. 112-229.

11. Michałowski A., Drzewa w krajobrazie kulturowym - natura między cywilizacja a kultura, Tom 1, Warszawa, ZOiKZP-O, 1991, p. 29.

12. Połucha I., Elkhatib O.A., Symbolika religijna roślin w chrześcijaństwie i islamie. W: Horyzonty Architektury Krajobrazu - Język Architektury Krajobrazu, Warszawa, Wyd. „Wieś Jutra”, 2010, p. 64-71.

13. Połucha I., Marks E., Młynarczyk K., Wybrane aspekty sztuki ogrodów na tle jej historycznego rozwoju. Humanistyka i Przyrodoznawstwo 6, 2000, p. 109-119.

14. Rylke J., Różańska A., Krogulec T., Ogrody. Historia architektury i sztuki ogrodowej, Warszawa, SGGW, 2002, p. 178.

15. Sędłak A., Połucha I., Symboliczny wymiar sacrum i profanum $w$ otoczeniu wspótczesnych obiektów sakralnych, W: Horyzonty Architektury Krajobrazu - Język Architektury Krajobrazu, Warszawa, Wyd. „Wieś Jutra”, 2010, p. 58-63.

16. Siewniak M., Mitkowska A., Tezaurus sztuki ogrodowej, Warszawa, Rytm, 1998, p. 1-351.

17. Swaryczewska M., Ogród i drzewo w europejskiej tradycji kulturowej, Olsztyn, UWM, 2003, p. 102-109.

18. Włodarczyk Z., Ogrody przyświatynne i klasztorne. Rekonstrukcja, rewaloryzacja, pielegnacja. Wrocław, Czasopismo techn. Architektura, Wyd. Politechniki Krakowskiej, 2003, p. 73-80.

19. Włodarczyk Z. Ogród roślin biblijnych jako ilustracja Biblii. Z badań nad Biblią, nr 9, Kraków, 2004, p. 57-58.

20. Zaraś-Januszkiewicz E., Szymczak-Piątek M., Wieczorek J., Symbolika roślin i związana z nimi obrzędowość w tradycji ludowej, Warszawa, SGGW, 2000, p. 143-144.

21. Internet source:

21a. www.bazylika-ketrzyn.olsztyn.opoka.org.pl, dostęp 2015-03-03.

21b. www.sanktuariumfatimskie.pl, dostęp 2015-07-09.

21c. www.sanktuariummaryjne.pl, dostęp 2015-01-23.

21d. www.stoczek.pl, dostęp 2015-02-23.

21e. www.swlipka.org.pl, dostęp 2015-02-09.

22. Table source: Siebiert J. 2007. Leksykon sztuki chrześcijańskiej. Tematy, postacie, symbole. Wyd. Jedność, Kielce. 